\title{
Natural Radioactivity Content in Intertidal Sand Samples of Marina and Besant Nagar Beaches of Chennai City, Tamilnadu, India
}

\author{
Lakshmi K S ${ }^{1}$, Meenakshisundaram V1, Punniyakotti J'* and Manju $\mathrm{N}^{1}$ \\ ${ }^{1}$ Department of Physics, Meenakshi College for Women (Autonomous), India \\ ${ }^{2}$ Department of Physics, Meenakshi Sundararajan Engineering College, India
}

*Corresponding author: Punniyakotti J, Assistant Professor, Department of Physics, Meenakshi Sundararajan Engineering College, Chennai- 600 024, India, Tel: +91-978 769 9314; Email: punniyakotti.j09@gmail.com; kotti_jpk@yahoo.co.in

\section{Research Article \\ Volume 3 Issue 1}

Received Date: January 06, 2020

Published Date: January 24, 2020

DOI: $10.23880 /$ ijnmrs-16000120

\section{Abstract}

The natural radioactivity content of $238 \mathrm{U}, 232 \mathrm{Th}$ and $40 \mathrm{~K}$ in the intertidal beach sands samples at ten sites each of Marina and Besant Nagar beaches of Chennai city has been analyzed using a 3"x3" NaI(Tl) scintillation detector based gamma ray spectroscopy. The radioactivity content in intertidal sands of Marina were found to be $4 \pm 3 \mathrm{~Bq} \cdot \mathrm{kg}^{-1}, 4 \pm 3 \mathrm{~Bq} \cdot \mathrm{kg}^{-1}$ and $248 \pm 28$ Bq. $\mathrm{kg}^{-1}$ respectively; the same were $4 \pm 3 \mathrm{~Bq} \cdot \mathrm{kg}^{-1}, 5 \pm 3 \mathrm{~Bq} \cdot \mathrm{kg}^{-1}$ and $242 \pm 29 \mathrm{~Bq} \cdot \mathrm{kg}^{-1}$ respectively in the beach sands of Besant Nagar. These activity levels at both beaches are, in general, much lower than other Indian and World average value. The radiological parameters for both the intertidal sand samples (Marina and Besant Nagar) are far lower than the UNSCEAR 2000 recommended values.

Keywords: Natural Radioactivity; Intertidal sands; Gamma ray spectrometry

Abbreviations: GPS: Global Positioning System; AEDE: Annual Effective Dose Equivalent; D: Absorbed Dose Rate; $\mathrm{Ra}_{\mathrm{eq}}$ : Radium Equivalent; $\mathrm{H}_{\mathrm{ext}}$ : External Hazard Index; BDL: Below Detectable Limit.

\section{Introduction}

The presence of natural radioactive isotopes is ubiquitous in nature. On the basis of their origin, naturally occuring radionuclides in the environment are classified as cosmogenic and primordial radionuclides. The cosmogenic radionuclides are mainly produced through interaction of the cosmic rays with target atoms in the atmosphere and to a much lesser extent in the earth. The three main cosmogenic contributors to external exposure at ground level are 7Be, $22 \mathrm{Na}$ and $24 \mathrm{Na}$. Primordial radionuclides of $238 \mathrm{U}$ and
232Th and their daughter products and 40K are long-lived radionuclides that have existed in the earth's crust throughout its history. Populations receive natural radiation exposure due to the presence of these naturally occurring primordial radionuclides in various geological formations like rocks, soil and beach sand [1]. Naturally occurring primordial radionuclides present in these formations are a key source of the environmental dose and these radionuclides may be transferred through beach sands-seawater-biota interface to human beings. Hence, humans should be aware of their natural environment with regard to the radiation effects due to the naturally occurring and induced radioactive elements.

The long term exposure to uranium and its daughters through inhalation has several health effects such as chronic lung diseases, acute leucopoenia, anemia and necrosis of 
the mouth. Thorium exposure may cause lung, pancreas, hepatic, bone, kidney cancers and leukemia [2]. The health of coastal and marine ecosystems is highly dependent on natural radioactivity levels of coastal sands. Therefore, the radionuclides concentrations and distributions, and its associated dose rates in the beach sands from coastal environments should be monitored. The distribution of primordial radionuclides in coastal sands have been reported by many investigators [3-16].

In a sea-coast environment, on the basis of physical properties of the naturally occurring primordial radionuclides, while uranium and potassium get dissolved in water, thorium is found accumulated with solid matter due to its insoluble nature [17]. These different physical properties make the study of estimating naturally occurring radionuclides in the intertidal zone and compare with the sediments of beach sand, slightly away from the intertidal zone, an interest one. The intertidal zone is the interface between the terrestrial and aquatic environments [18]. The solubility characteristics of radionuclides and getting deposited in beach sands play a predominant role in aquatic radioecology $[17,18]$. The contribution of absorbed dose due to $238 \mathrm{U}, 232 \mathrm{Th}$ and $40 \mathrm{~K}$ in the marine coastal environment may be of concern to the safety of biotic life, the marine food chain and ultimately consumption of the seafood. Hence, it acquires importance to monitor the intertidal zone, from the point of view of transport of radionuclides and their deposition in the adjoining beach sands. The mapping of current status of the profile of naturally occurring radionuclides at any given site will be of great significance and help in establishing the valuable data base. Such a study has been undertaken in the environs of two well-known beaches viz., Marina and Besant Nagar in the Chennai city of Tamilnadu state, India.

\section{Materials and Methods}

\section{Study Area}

Chennai City, the capital of Tamilnadu State, India, popularly known as Madras in the yesteryears, is on the southeast coast of India in the northeast of Tamilnadu State on a flat coastal plain known as eastern coastal plains. The Chennai City can be said as gateway to south India. According to the provisional results of 2011 census, the city had 4.68 million residents making it the sixth most populous city in India; the urban agglomeration, which comprises the city, its suburbs and outskirts, was home to approximately 8.9 million, making it the fourth most populous metropolitan area in the country and $31^{\text {st }}$ largest urban area in the world. A coastal city, Chennai has a lot of beaches, which both local people as well as tourist flock to, to enjoy splashing in the water and soaking in some sun and sand. The most prominent beaches in the Chennai city are Marina and Besant Nagar. Marina beach has etched a mark on the world map as the second longest beach all over the world and the longest one in India. It stretches to a total of approximately $12 \mathrm{~km}$. The Marina beach is in continuation with the Bay of Bengal of the eastern coast of India. Similarly, the Besant Nagar beach is towards the eastern coast of Tamilnadu and is considered as one of the cleanest beaches of Chennai city. These two beaches are taken as a study area of the present study. From each of Marina and Besant Nagar beaches, ten sites were selected and numbered as M1 to M10 and B1 to B10 respectively (Figure 1). The sampling sites were recorded in terms of degree-minute-second (Latitudinal and Longitudinal positions) using a hand-held Global Positioning System (GPS) unit (Model: GARMIN GPS map76).

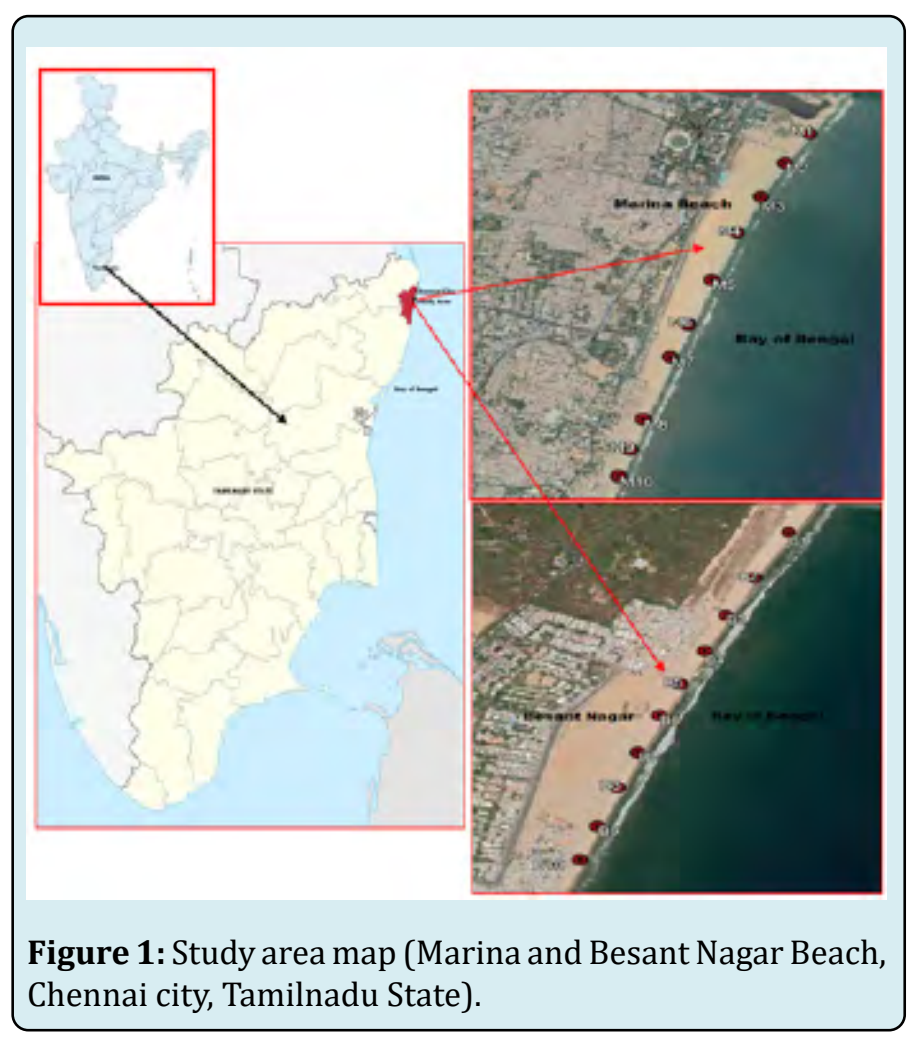

Sample Collection and Preparation Techniques

The collected sand samples were uniformly mixed, sieved and air dried and further dried in an oven at temperature of $100^{\circ} \mathrm{C}$ to $120^{\circ} \mathrm{C}$ for an hour to remove the moisture content. Each sample was transferred to a $250 \mathrm{ml}$ plastic container having diameter of $\sim 6 \mathrm{~cm}$ and height of $\sim 9.5 \mathrm{~cm}$. The container with an inner cap was sealed hermetically and externally an adhesive tape was put making it leak-tight and kept aside for about a month to attain secular equilibrium between radium and its daughter products before being taken for gamma ray spectrometric analysis. The net weight of the samples was determined before counting [19]. 


\section{Gamma Ray-Spectroscopy}

A 3"x3" NaI(Tl) scintillation detector TEC, USA) based gamma-ray spectrometer (Electronics Corporation of India Limited, India) was used for spectral measurements to enable one to cover the entire energy range of the naturally occurring radionuclides up to $2.6 \mathrm{MeV}$ (energy of 208Tl, one of the gamma emitting daughter products of $232 \mathrm{Th}$ ). The detector is shielded by $15 \mathrm{~cm}$ thick lead on all sides including at the top to reduce background due to cosmic ray component by almost $98 \%$. The inner sides of the lead shielding are lined by $2 \mathrm{~mm}$ thick cadmium and $1 \mathrm{~mm}$ thick copper to cut off lead $\mathrm{x}$-rays and cadmium x-rays respectively. These graded-lining shield materials help in further reducing the background component especially in the low energy region as well as in increasing the signal to noise ratio.

Standard sources of the primordial radionuclides obtained from IAEA in the similar geometry and having soil equivalent matrix, were used to determine the efficiency of the detector for various energies. The sealed sand samples were placed on the top of 3"x3" $\mathrm{NaI}(\mathrm{Tl})$ detector and count spectra were obtained for each of the sand sample. Each sample was counted for 10,000 seconds and the net radioactivity content of the three primordial nuclides viz., 40K, 232Th and $238 \mathrm{U}$ are deduced from the count spectra. The region under the peaks corresponding to $1.46 \mathrm{MeV}$ (40K), $1.764 \mathrm{MeV}$ (214Bi) and $2.614 \mathrm{MeV}$ (208Tl) energies are considered to arrive at the radioactivity levels of $40 \mathrm{~K}, 238 \mathrm{U}$ and $232 \mathrm{Th}$ respectively.
The minimum detectable activity (MDA) of each of the three primordial radionuclides with $95 \%$ confidence level $(2 \sigma)$ is determined from the background radiation spectrum obtained for the same counting time as was done for the sand samples. The estimated MDA values are $2.22 \mathrm{~Bq} \cdot \mathrm{kg}^{-1}$ for 238U, 2.15 Bq.kg-1 for 232 Th and $8.83 \mathrm{~Bq} \cdot \mathrm{kg}^{-1}$ for $40 \mathrm{~K}$ [19].

\section{Results and Discussion}

\section{Distribution of Primordial Radionuclides of 238U, 232Th And 40K}

The radioactivity content of three primordial radionuclides (238U, 232Th and 40K) are determined in intertidal sands of Marina and Besant Nagar beaches are given in Table 1. As can be noted from Table 1, the radioactivity content in the intertidal sands of Marina beach for $238 \mathrm{U}, 232 \mathrm{Th}$ and $40 \mathrm{~K}$ ranged from BDL to $16 \pm 6 \mathrm{~Bq} \cdot \mathrm{kg}^{-1}$ with an average value of $4 \pm 3$ Bq. $\mathrm{kg}^{-1}$, BDL to $9 \pm 5$ Bq. $\mathrm{kg}^{-1}$ with an average value of $4 \pm 3$ Bq. $\mathrm{kg}^{-1}$ and $213 \pm 27$ Bq. $\mathrm{kg}^{-1}$ to $290 \pm 29 \mathrm{~Bq} \cdot \mathrm{kg}^{-1}$ with an average value of $248 \pm 28 \mathrm{~Bq} \cdot \mathrm{kg}^{-1}$ respectively. For the Besant Nagar beach, the activity content ranged from BDL to $12 \pm 6 \mathrm{~Bq} \cdot \mathrm{kg}^{-1}$ with an average value of $4 \pm 3 \mathrm{~Bq} \cdot \mathrm{kg}^{-1}$, BDL to $18 \pm 5 \mathrm{~Bq} \cdot \mathrm{kg}^{-1}$ with an average value of $5 \pm 3$ Bq.kg ${ }^{-1}$ and $130 \pm 27$ Bq. $\mathrm{kg}^{-1}$ to $326 \pm 31$ Bq. kg ${ }^{-1}$ with an average value of $242 \pm 29 \mathrm{~Bq}^{\mathrm{kg}}{ }^{-1}$ respectively. All the three primordial radionuclides (238U, $232 \mathrm{Th}$ and $40 \mathrm{~K}$ ) are far lesser than the world average value of 33,45 and 420 Bq.kg ${ }^{-1}$ respectively.

\begin{tabular}{|c|c|c|c|c|c|c|c|}
\hline \multirow{3}{*}{ Site Name } & \multirow{2}{*}{\multicolumn{3}{|c|}{$\begin{array}{c}\text { Marina Beach } \\
\text { Radioactivity content }\left(\mathrm{Bq} \cdot \mathrm{Kg}^{-1}\right) \\
\end{array}$}} & \multirow{3}{*}{ Site Name } & \multirow{2}{*}{\multicolumn{3}{|c|}{$\begin{array}{c}\text { Besant Nagar Beach } \\
\text { Radioactivity content }\left(\mathrm{Bq} \cdot \mathrm{Kg}^{-1}\right) \\
\end{array}$}} \\
\hline & & & & & & & \\
\hline & ${ }^{238} \mathrm{U}$ & ${ }^{232} \mathrm{Th}$ & ${ }^{40} \mathrm{~K}$ & & ${ }^{238} \mathrm{U}$ & ${ }^{232} \mathrm{Th}$ & ${ }^{40} K$ \\
\hline M1 & $16 \pm 6$ & BDL & $235 \pm 28$ & $\mathrm{~B} 1$ & BDL & BDL & $250 \pm 30$ \\
\hline M2 & BDL & $8 \pm 5$ & $256 \pm 28$ & $\mathrm{~B} 2$ & $8 \pm 6$ & $6 \pm 4$ & $256 \pm 28$ \\
\hline M3 & BDL & BDL & $243 \pm 27$ & B3 & BDL & BDL & $250 \pm 29$ \\
\hline M4 & BDL & BDL & $213 \pm 27$ & B4 & BDL & BDL & $233 \pm 28$ \\
\hline M5 & BDL & BDL & $262 \pm 28$ & B5 & BDL & BDL & $303 \pm 28$ \\
\hline M6 & BDL & BDL & $219 \pm 28$ & B6 & BDL & BDL & $230 \pm 29$ \\
\hline M7 & BDL & BDL & $273 \pm 29$ & B7 & BDL & $8 \pm 5$ & $326 \pm 29$ \\
\hline M8 & BDL & BDL & $236 \pm 28$ & $\mathrm{~B} 8$ & BDL & BDL & $205 \pm 27$ \\
\hline M9 & BDL & BDL & $251 \pm 28$ & B9 & $12 \pm 6$ & $7 \pm 5$ & $130 \pm 28$ \\
\hline M10 & BDL & $9 \pm 5$ & $290 \pm 28$ & $\mathrm{~B} 10$ & BDL & $18 \pm 5$ & $235 \pm 29$ \\
\hline Minimum & BDL & BDL & $213 \pm 27$ & Minimum & BDL & BDL & $130 \pm 27$ \\
\hline Maximum & $16 \pm 6$ & $9 \pm 5$ & $290 \pm 29$ & Maximum & $12 \pm 6$ & $18 \pm 5$ & $326 \pm 31$ \\
\hline Average & $4 \pm 3$ & $4 \pm 3$ & $248 \pm 28$ & Average & $4 \pm 3$ & $5 \pm 3$ & $242 \pm 29$ \\
\hline
\end{tabular}

${ }^{a}$ BDL (Below Detectable Limit) for 238U - $2.22 \mathrm{~Bq} \cdot \mathrm{kg}^{-1}$ and 232Th-2.15 Bq.kg-1

Table 1: Radioactivity content of 238U, $232 \mathrm{Th}$ and $40 \mathrm{~K}$ in different beaches. 
In all the sites, all the three radionuclides of $238 \mathrm{U}$, $232 \mathrm{Th}$ and $40 \mathrm{~K}$ in the beach sand samples are well below the UNSCEAR 2000 world value of 33, 45 and 420 Bq. $\mathrm{kg}^{-1}$ respectively [20] and hence may not have any impact on the ecosystem as well as to the tourists, and members of public residing there.

\section{Radiological Parameters}

It would be of interest to determine the radiological parameters and their contribution to the background radiation levels of Marina and Besant Nagar beach, Chennai city, Tamilnadu, India to the benefit of critical population and other members of public. In this study, the four radiological parameters viz.

- Absorbed Dose Rate (D)

- Annual Effective Dose Equivalent (AEDE)

- Radium Equivalent $\left(\mathrm{Ra}_{\mathrm{eq}}\right)$

- External Hazard Index $\left(\mathrm{H}_{\text {ext }}\right)$ is estimated.

\section{Absorbed Dose rate (D)}

The absorbed dose rate in air at $1 \mathrm{~m}$ above the ground surface depends on the specific activity of 238U, 232Th and
40K. The large percentage of exposure in the form of gamma radiation is obtained from terrestrial radionuclides. There is a direct correlation between terrestrial gamma radiation exposure and radionuclide concentrations. If a radionuclide activity is known, then its exposure dose rate in air at $1 \mathrm{~m}$ above the ground can be calculated using the formula proposed by UNSCEAR-2000 [20]. The measured specific activity values of $238 \mathrm{U}, 232 \mathrm{Th}$ and $40 \mathrm{~K}$ are converted into dose rates using UNSCEAR-2000 conversion factors of 0.462 , 0.604 and 0.0417 nGy.h ${ }^{-1}$ per Bq.kg-1 respectively. These factors are used to arrive at the total absorbed dose rate (D) using the following equation:

$$
\left.\mathrm{D}\left(\mathrm{nGy}^{-1}\right)^{-1}\right)=(0.462 \mathrm{AU})+(0.604 \mathrm{ATh})+(0.0417 \mathrm{AK})(1)
$$

Where, AU, ATh and AK are the activity content of $238 \mathrm{U}$, 232Th and 40K (Bq. $\mathrm{kg}^{-1}$ ) respectively. The estimated absorbed dose rates for intertidal sand samples collected at Marina beach and Besant Nagar beaches are given in Table 2. For Marina Beach, the absorbed dose rates are varying from $11 \pm 3$ nGy.h ${ }^{-1}$ to $18 \pm 5 \mathrm{nGy.h}^{-1}$ with an average value of $14 \pm 4$ nGy. $\mathrm{h}^{-1}$. Similarly, for Besant Nagar, the absorbed dose rate ranged from $10 \pm 3 \mathrm{nGy.h}{ }^{-1}$ to $22 \pm 7 \mathrm{nGy} \cdot \mathrm{h}^{-1}$ with an average value of $15 \pm 4$ nGy.h ${ }^{-1}$.

\begin{tabular}{|c|c|c|c|c|c|c|c|c|c|}
\hline \multirow{3}{*}{$\begin{array}{c}\text { Site } \\
\text { Name }\end{array}$} & \multirow{2}{*}{\multicolumn{4}{|c|}{$\begin{array}{c}\text { Marina Beach } \\
\text { Radiological Parameters }\end{array}$}} & \multirow{3}{*}{$\begin{array}{c}\text { Site } \\
\text { Name }\end{array}$} & \multirow{2}{*}{\multicolumn{4}{|c|}{$\begin{array}{c}\text { Besant Nagar Beach } \\
\text { Radiological Parameters }\end{array}$}} \\
\hline & & & & & & & & & \\
\hline & $\mathbf{D}\left(n G y \cdot h^{-1}\right)$ & $\begin{array}{c}\text { AEDE } \\
\left(\mu S v \cdot y^{-1}\right)\end{array}$ & $\begin{array}{c}\mathbf{R a}_{\mathbf{e}_{\mathbf{e q}}}(B q . \\
\left.\mathrm{kg}^{-1}\right)\end{array}$ & $\mathbf{H}_{\text {ext }}$ & & $\mathbf{D}\left(n G y \cdot h^{-1}\right)$ & $\begin{array}{c}\text { AEDE } \\
\left(\mu S v \cdot y^{-1}\right)\end{array}$ & $\begin{array}{c}\mathbf{R a}_{\mathbf{e q}}(B q . \\
\left.k^{-1}\right)\end{array}$ & $\mathbf{H}_{\text {ext }}$ \\
\hline M1 & $18 \pm 5$ & $22 \pm 6$ & $36 \pm 11$ & 0.1 & B1 & $12 \pm 3$ & $15 \pm 4$ & $24 \pm 7$ & 0.07 \\
\hline M2 & $17 \pm 5$ & $20 \pm 6$ & $33 \pm 11$ & 0.09 & $\mathrm{~B} 2$ & $17 \pm 7$ & $21 \pm 8$ & $35 \pm 15$ & 0.1 \\
\hline M3 & $12 \pm 3$ & $15 \pm 4$ & $24 \pm 7$ & 0.06 & B3 & $12 \pm 3$ & $15 \pm 4$ & $24 \pm 7$ & 0.07 \\
\hline M4 & $11 \pm 3$ & $13 \pm 4$ & $21 \pm 7$ & 0.06 & B4 & $12 \pm 3$ & $14 \pm 4$ & $23 \pm 7$ & 0.06 \\
\hline M5 & $13 \pm 3$ & $16 \pm 4$ & $25 \pm 7$ & 0.07 & B5 & $15 \pm 3$ & $18 \pm 4$ & $28 \pm 7$ & 0.08 \\
\hline M6 & $11 \pm 3$ & $14 \pm 4$ & $22 \pm 7$ & 0.06 & B6 & $12 \pm 3$ & $14 \pm 4$ & $23 \pm 7$ & 0.06 \\
\hline M7 & $13 \pm 3$ & $17 \pm 4$ & $26 \pm 7$ & 0.07 & B7 & $19 \pm 5$ & $23 \pm 6$ & $38 \pm 11$ & 0.1 \\
\hline M8 & $12 \pm 3$ & $15 \pm 4$ & $23 \pm 7$ & 0.06 & B8 & $10 \pm 3$ & $13 \pm 4$ & $21 \pm 7$ & 0.06 \\
\hline M9 & $12 \pm 3$ & $15 \pm 4$ & $24 \pm 7$ & 0.07 & B9 & $15 \pm 7$ & $18 \pm 8$ & $32 \pm 15$ & 0.09 \\
\hline M10 & $18 \pm 5$ & $22 \pm 6$ & $36 \pm 11$ & 0.1 & $\mathrm{~B} 10$ & $22 \pm 5$ & $26 \pm 6$ & $46 \pm 12$ & 0.13 \\
\hline Min. & $11 \pm 3$ & $13 \pm 4$ & $21 \pm 7$ & 0.06 & Min. & $10 \pm 3$ & $13 \pm 4$ & $21 \pm 7$ & 0.06 \\
\hline Max & $18 \pm 5$ & $22 \pm 6$ & $36 \pm 11$ & 0.1 & Max. & $22 \pm 7$ & $26 \pm 6$ & $46 \pm 12$ & 0.13 \\
\hline Avg & $14 \pm 4$ & $17 \pm 5$ & $27 \pm 8$ & 0.07 & Avg. & $15 \pm 4$ & $18 \pm 5$ & $29 \pm 10$ & 0.08 \\
\hline
\end{tabular}

Table 2: Radiological parameters in Marina and Besant Nagar beach sands.

Similar studies have been carried out by various authors for other parts of Indian coastal regions and the range of absorbed dose rate values obtained in these studies are compared and given in Figure 2. It may be seen from Figure
2 that the average absorbed dose rate values are much lower than the world average value of $57 \mathrm{nGy \cdot h^{-1 }}$ [20] as well as other Indian coastal regions. 


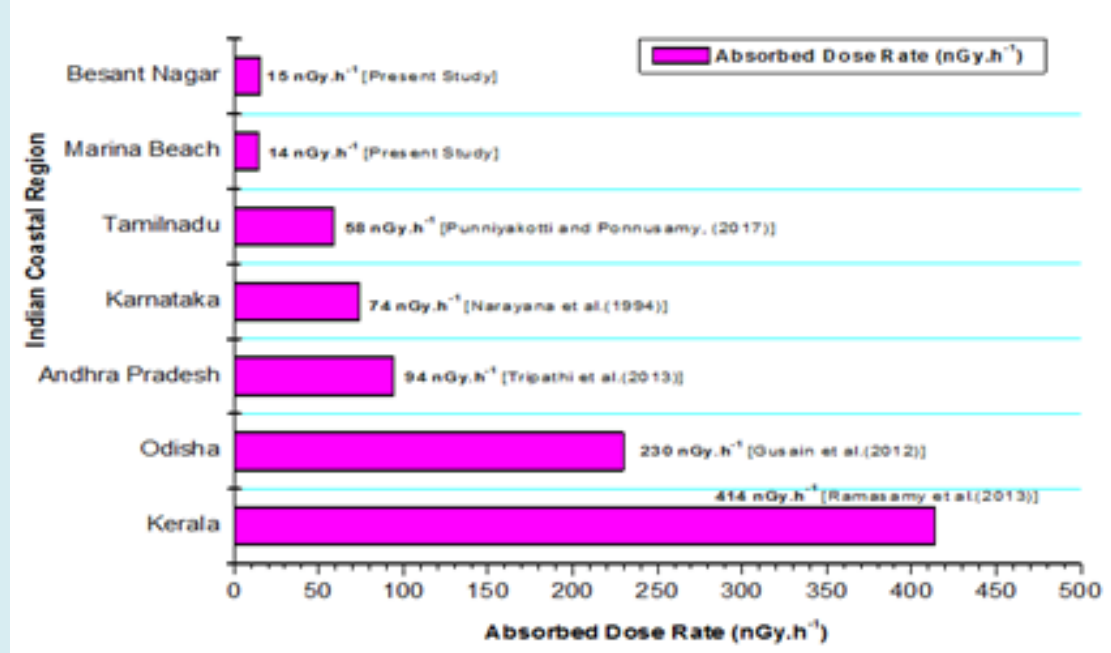

Figure 2: Comparison of absorbed dose rate in beach sand of different parts of India.

\section{Annual Effective Dose Equivalent (AEDE)}

As the study area is essentially a coastal one, importance is given to critical population viz., fishermen communities who live along the coastal strip and spend most of their time in beaches for their daily livelihood. In view of this, if absorbed dose rate value (D) is known, then annual effective dose equivalent (AEDE) that would be obtained by the members of public can be arrived using the conversion coefficient of $0.7 \mathrm{~Sv} \mathrm{~Gy}^{-1}$ from absorbed dose in air to effective dose with an outdoor occupancy factor of 0.2 reported by UNSCEAR 2000 [20]. Therefore, the AEDE is calculated for outdoor using the formula given below:

\section{AEDE (outdoor) $=$ Absorbed dose rate (D) $\times 8760 \mathrm{~h} \times 0.7$ Sv.Gy ${ }^{-1} \times 0.2 \times 10^{-3}\left(\mu\right.$ Sv. $\left.y^{-1}\right)(2)$

Where, absorbed dose rate (D) is in nGy.h ${ }^{-1}$. For Marina Beach, the minimum, maximum and average values of AEDE for beach sands are found to be $13 \pm 4 \mu$ Sv. $^{-1}, 22 \pm 6 \mu$ Sv. $^{-1}$ and $17 \pm 5 \mu$ Sv. $y^{-1}$ respectively (Table 2 ). The minimum, maximum and average value of AEDE for Besant Nagar beach sands are $13 \pm 4 \mu$ Sv. $^{-1}, 26 \pm 6 \mu$ Sv. $^{-1}$ and $18 \pm 5 \mu$ Sv. $^{-1}$ respectively. The annual effective dose equivalent values obtained for other Indian coastal regions are: $2360 \mu$ Sv. $^{-1}$ in Chhatrapur beach of Orissa [12], $120 \mu \mathrm{Sv}^{-1} \mathrm{y}^{-1}$ in Andhra coast [13] and $507 \mu$ Sv. $y^{-1}$ in Kerala [14]. All these values are higher than the average value of $17 \pm 5 \mu \mathrm{Sv}_{\mathrm{y}} \mathrm{y}^{-1}$ and $18 \pm 5 \mu \mathrm{Sv}_{\mathrm{y}} \mathrm{y}^{-1}$ obtained with the present study for Marina and Besant Nagar beach sand samples respectively. As compared to world average value ( $\left.450 \mu \mathrm{Sv} \cdot \mathrm{y}^{-1}\right)$, the average annual effective dose equivalent for both Marina $\left(17 \pm 5 \mu\right.$ Sv. $\left.y^{-1}\right)$ and Besant Nagar Beach $(18 \pm 5$ $\mu \mathrm{Sv} \mathrm{y}^{-1}$ ) sands are also very much lesser.

\section{Radium Equivalent $\left(\mathrm{Ra}_{\mathrm{eq}}\right.$ ) Activity}

Exposure to radiation can be defined in terms of many parameters. It is well known that Raeq activity is one of the widely used hazard indices. Raeq concept allows a single index or a number to describe the gamma output from different mixtures of $238 \mathrm{U}, 232 \mathrm{Th}$ and $40 \mathrm{~K}$ in a material. Raeq in Bq. $\mathrm{kg}^{-1}$ can be calculated as follows [21].

$$
\mathrm{Ra}_{\mathrm{eq}}=\mathrm{AU}+1.43 \mathrm{ATh}+0.077 \mathrm{AK}\left(\mathrm{Bq} \cdot \mathrm{kg}^{-1}\right)
$$

Where, AU, ATh and AK are the activity content of $238 \mathrm{U}$, 232Th and $40 \mathrm{~K}$ (Bq. $\mathrm{kg}^{-1}$ ) respectively. From Table 2, the range of Raeq levels for beach sands of Marina beach sand samples varies from $21 \pm 7$ Bq. $\mathrm{kg}^{-1}$ to $36 \pm 11 \mathrm{~Bq} \cdot \mathrm{kg}^{-1}$ with an average of $27 \pm 8$ Bq. kg ${ }^{-1}$. For Besant Nagar beach, the Raeq levels varying from $21 \pm 7 \mathrm{~Bq} \cdot \mathrm{kg}^{-1}$ to $46 \pm 15 \mathrm{~Bq} \cdot \mathrm{kg}^{-1}$ with an average of $29 \pm 10 \mathrm{~Bq} \cdot \mathrm{kg}^{-1}$. These values are far lower than the recommended value of $370 \mathrm{~Bq} \cdot \mathrm{kg}^{-1}$ for safe limit [21].

\section{External Hazard Index $\left(\mathrm{H}_{\text {ext }}\right)$}

The external hazard index $\left(\mathrm{H}_{\text {ext }}\right)$ is calculated for the marina and Besant Nagar beach intertidal zone sand samples using the following equation on the basis of model proposed by Beretka and Mathew [21].

$$
\mathrm{H}_{\mathrm{ext}}=\mathrm{AU} / 370+\mathrm{ATh} / 259+\mathrm{AK} / 4810 \text { (4) }
$$

Where, AU, ATh and AK are the activity content of $238 \mathrm{U}$, 232Th and $40 \mathrm{~K}\left(\mathrm{~Bq} \cdot \mathrm{kg}^{-1}\right)$, respectively. The external hazard index $\left(\mathrm{H}_{\text {ext }}\right)$ for Marina Beach sands varied from 0.06 to 0.10 with an average value of 0.07. Similarly, for Besant Nagar beach, the external hazard index values varied from 0.06 
to 0.13 with an average value of 0.08 . The external hazard index values are fat lower than ICRP recommended level of one [21]. Here, both Marina and Besant Nagar beaches sand samples are much lower than unity and these sand samples do not pose any radiological hazard to coastal environment.

\section{Conclusion}

The natural radioactivity content of $238 \mathrm{U}, 232 \mathrm{Th}$ and $40 \mathrm{~K}$ in the intertidal sand samples of Marina and Besant Nagar beaches of Chennai city have been analyzed. From the gamma spectral analysis, the average activity content of $238 \mathrm{U}, 232 \mathrm{Th}$ and $40 \mathrm{~K}$ in sand samples collected at both beaches are $4 \pm 3$ Bq.kg-1 $4 \pm 3$ Bq. $\mathrm{kg}^{-1}, 4 \pm 3$ Bq. $\mathrm{kg}^{-1}, 54 \pm 3$ Bq. $\mathrm{kg}^{-1}$ and $248 \pm 28 \mathrm{~Bq} \cdot \mathrm{kg}^{-1}, 242 \pm 29 \mathrm{~Bq} \cdot \mathrm{kg}^{-1}$ respectively. All the three primordial radionuclides are much lesser than the world average value. All the four radiological parameters (absorbed dose rate, annual effective dose equivalent, radium equivalent and external hazard index) for the intertidal sand samples of both Marina and Besant Nagar beaches of Chennai city are very much lesser than the world average value/recommended safe limit. Hence, the natural radioactivity content and associated radiological parameters in both Marina and Besant Nagar beach sands do not pose any radiation effect to the ecosystem and the members of public residing in the environments.

\section{References}

1. Al-Trabulsy HA, Khater AEM, Habbani FI (2011) Radioactivity levels and radiological hazard indices at the Saudi coastline of the Gulf of Aqaba. Radiat Phys Chem 80(3): 343-348.

2. Taskin H, Karavus M, Ay P, Topuzoglu A, Hindiroglu S, et al. (2009) Radionuclide concentrations in soil and lifetime cancer risk due to the gamma radioactivity in Kirklareli, Turkey. J Environ Radioact 100(1): 49-53.

3. Narayana Y, Somashekarappa HM, Radhakrishna AP, Balakrishna KM, Siddappa K (1994) External gamma radiation dose rates in coastal Karnataka. J Radiol Prot 14(3): 257-264.

4. Kannan V, Rajan MP, Iyengar MAR, Ramesh R (2002) Distribution of natural and anthropogenic radionuclides in soil and beach sands samples of Kalpakkam (India) using hyper pure germanium (HPGe) gamma ray spectrometry. Appl Radiat Isot 57(1): 109-119.

5. Mohanty AK, Sengupta D, Das SK, Saha SK, Van KV (2004) Natural radioactivity and radiation exposure in the high background area at Chhatrapur beach placer deposit of Orissa, India. J Environ Radioact 75(1): 15-33.

6. Seddeek MK, Badran HM, Sharshar T, Elnimr T (2005)
Characteristics, spatial distribution and vertical profile of gamma-ray emitting radionuclides in the coastal environment of North Sinai. J Environ Radioact 84(1): 21-50.

7. Lakshmi KS, Selvasekarapandian S, Khanna D, Meenakshisundaram V (2005) Primordial radionuclides concentrations in the beach sands of East coast region of Tamilnadu, India. Int Congr Ser 1276: 323-324.

8. Orgun Y, Altınsoy N, Sahin SY, Gungor Y, Gultekin AH, et al. (2007) Natural and anthropogenic radionuclides in rocks and beach sands from Ezine region (Çanakkale), Western Anatolia, Turkey. Appl Radiat Isot 65(6): 739747.

9. Uosif MAM, El-Taher A, Abbaddy Adel GE (2008) Radiological significance of beach sand used for climatotheraphy from Safaga, Egypt. Radiat Prot Dosim 131(3): 331-339.

10. Malain D, Regan PH, Bradley DA, Matthews M, Al-Sulaiti HA, etal. (2004) An evaluation of the natural radioactivity in Andaman beach sand samples of Thailand after the 2004 tsunami. Appl Radiat Isot 70(8): 1467-1474.

11. Carvalho C, Anjos RM, Veiga R, Macario K (2011) Application of radiometric analysis in the study of provenance and transport process of Brazillian coasts sediments. J Environ Radioact 102(2): 185-192.

12. Gusain GS, Rautela BS, Sahoo SK, Ishikawa T, Prasad G, et al. (2012) Dsitribution of terrestrial gamma radiation dose rate in eastern coastal area of Odisha, India. Radiat Prot Dosimetry 152(1-3): 42-45.

13. Tripathi RM, Patra AC, Mohapatra S, Sahoo SK, Kumar AV, et al. (2013) Natural radioactivity in surface marine sediments near the shore of Vizag, Southeast India and associated radiological risk. Journal of Radioanalytical and Nuclear Chemistry 295: 1829-1835.

14. Ramasamy V, Sundarrajan M, Paramasivam K, Meenakshisundaram V, Suresh G (2013) Assessment of spatial distribution and radiological hazardous nature of radionuclides in high background radiation area, Kerala, India. Appl Radiat Isot 73: 21-31.

15. Yingnan Huang, Xinwei Lu, Xiang Ding, Tingting Feng (2015) Natural radioactivity level in beach sand along the coast of Xiamen Island, China. Mar Pollut Bull 91(1): 357-361.

16. Punniyakotti J, Ponnusamy V (2017) Radionuclides of $238 \mathrm{U}, 232 \mathrm{Th}$ and $40 \mathrm{~K}$ in beach sand of southern regions in Tamilnadu State, India (Post-Tsunami). Indian J Pure 
Ap Phy 55(3): 218-230.

17. A El-Taher, Madkour HA (2011) Distribution and environmental impacts of metals and natural radionuclides in marine sediments in-front of different wadies mouth along the Egyptian Red sea coast. Appl Radiat Isot 69(2): 550-558.

18. Eleonora S Carol, Eduardo E Kruse, Eduadro L Tavani (2012) Physicochemical characterization of sediments from the coastal wetland of Saborombon Bay, Argentina. J S Am Earth Sci 34: 26-32.
19. Punniyakotti J, Ponnusamy V (2017) Depth-wise distribution of $238 \mathrm{U}, 232 \mathrm{Th}$ and $40 \mathrm{~K}$ in sand samples of high background radiation areas (Tamilnadu coast), India. J Radioanal Nucl Chem 311(3): 1875-1881.

20. UNSCEAR (2000) Sources and Effects of Ionizing Radiation. Report of the United Nations Scientific Committee on the Effects of Atomic Radiation to the General Assembly (United Nations, New York, USA).

21. Beretka J, Mathew PJ (1985) Natural radioactivity of Australian building materials, industrial wastes and by products. Health Phys 48(1): 87-95. 